\title{
The Determinants of Vietnam's Exports to CPTPP Members: A Gravity Model Approach
}

\author{
Phan Thanh Hoan ${ }^{1}$ \\ ${ }^{1}$ College of Economics, Hue University, Hue, Vietnam \\ Correspondence: Phan Thanh Hoan, Ph.D, College of Economics, Hue University, Hue, Vietnam.
}

Received: May 18, 2020

Accepted: July 31, 2020

Online Published: September 13, 2020

doi:10.5430/rwe.v11n5p341

URL: https://doi.org/10.5430/rwe.v11n5p341

\begin{abstract}
This study examines the determinants of Vietnam's export to CPTPP by applying the gravity model to panel data for the period of 2003-2016. Besides the conventional variables such as economic size and distance between trade parties; exchange rate, bilateral tariff, income gap, and foreign direct investment (FDI) are included in the model. The results show that the export of Vietnam to CPTPP is influenced by economic size (GDP), income gap, bilateral tariffs, FDI, and exchange rate. Among the impact factors, economic size, exchange rate, and income gap have significant impact on Vietnam's exports to CPTPP. The trade potential between Vietnam and CPTPP is also calculated based on gravity model results. Vietnam's export to CPTPP is predicted to expand significantly in its member markets.
\end{abstract}

Keywords: export, gravity model, panel data, Vietnam, CPTPP

\section{Introduction}

Vietnam is evaluating the economic gains from deepening regional trade integration under free trade agreements. The two major new agreements include Comprehensive and Progressive Agreement for Trans-Pacific Partnership (CPTPP) to be signed in March 2018 following the US departure from the Trans-Pacific Partnership (TPP) in January 2017 and the Regional Comprehensive Economic Partnership (RCEP) in its 21st round of negotiations.

Among the FTAs that Vietnam is pursuing, CPTPP is of particular importance for a number of reasons. Firstly, CPTPP has population of more than 500 million people and GDP of over 10,000 billion USD, accounting for 15.84\% of Vietnam's total import-export turnover. Second, CPTPP is also Vietnam's first free trade agreement with Peru, Canada and Mexico, in which Canada and Mexico are the 11th and 14th largest economies in the world. Third, among the countries participating in CPTPP today, Vietnam is the country with the lowest per capita income and has some special comparative advantages that no country has, namely the processing industry. Labor intensive and industries are now subject to high tax rates such as textiles.

The gravity model has been extensively used in international trade research for many years because of its considerable empirical robustness and explanatory power (see Kepaptsoglou, K., Karlaftis, M., and Tsamboulas, D., 2010). However, it appears that there are limited studies of trade between Vietnam and CPTPP using gravity model. Recent and typical study on Vietnam's exports to CPTPP is by Su Ha, Van \& Hoi, Le. (2019). In this study, the authors have also used gravity model with conventional variables such as GDP, Tariff, exchange rate, and geographical distance. However, this study does not use export volume with members of CPTPP (panel data) and the model is estimated for export to CPTPP at aggregate level and selected CPTPP's members. Therefore, this paper aims to: (i) apply panel data analysis to the trade relationship between Vietnam and CPTPP; (ii) predict the trade potential between Vietnam and CPTPP using gravity model estimates; and (iii) contribute to the literature on Vietnam and CPTPP trade situation and prospects.

The structure of the paper is as follows. Section 2 summarizes the trade development between Vietnam and CPTPP. Section 3 presents the hypotheses to be tested, data collection and the empirical model applied for Vietnam-CPTPP bilateral trade. The discussion is in Section 4, and Section 5 concludes the paper.

\section{Overview of Vietnam - CPTPP Trade}

In terms of each industry, export of electric and electronic products (HS code 84-85) accounted for the highest proportion (38.8\%), followed by textiles (13.9\%), footwear (6.56\%), and fuel $(3.71 \%)$ of Vietnam's total export 
value to CPTPP market in 2017 (Table 1). In terms of growth rate, in the above key products, footwear has a growth rate of 3 years, nearly $15 \%$, electric products (10.6\%), and textiles (7.6\%), in then exports of fuel goods fell sharply, about $20 \%$ per year.

Table 1. Vietnam export by sector in CPTPP in the period of 2015-2017

Unit: million USD

\begin{tabular}{|c|c|c|c|c|c|c|c|}
\hline \multirow{2}{*}{ Sector } & \multicolumn{2}{|c|}{2015} & \multicolumn{2}{|c|}{2016} & \multicolumn{2}{|c|}{2017} & \multirow{2}{*}{$\begin{array}{c}\text { Growth } \\
(\%)\end{array}$} \\
\hline & Value & $\%$ & Value & $\%$ & Value & $\%$ & \\
\hline 01-05_Animal & $1,096.9$ & 3.11 & $1,081.2$ & 2.97 & $1,268.6$ & 3.06 & 7.55 \\
\hline 06-15_Vegetable & $1,166.9$ & 3.31 & $1,143.9$ & 3.14 & $1,211.8$ & 2.92 & 1.90 \\
\hline 16-24_FoodProd & $1,031.4$ & 2.93 & $1,021.2$ & 2.80 & $1,129.6$ & 2.72 & 4.65 \\
\hline 25-26_Minerals & 318.2 & 0.90 & 222.5 & 0.61 & 202.0 & 0.49 & -20.32 \\
\hline 27-27_Fuels & $2,457.0$ & 6.97 & 812.9 & 2.23 & $1,539.0$ & 3.71 & -20.86 \\
\hline 28-38_Chemicals & 683.4 & 1.94 & 697.0 & 1.91 & 818.8 & 1.97 & 9.46 \\
\hline 39-40_PlastiRub & $1,277.4$ & 3.62 & $1,199.2$ & 3.29 & $1,450.5$ & 3.50 & 6.56 \\
\hline 41-43_HidesSkin & 688.0 & 1.95 & 806.6 & 2.21 & 898.0 & 2.16 & 14.25 \\
\hline 44-49_Wood & $1,041.5$ & 2.95 & 998.1 & 2.74 & $1,031.5$ & 2.49 & -0.48 \\
\hline 50-63_TextCloth & $4,991.5$ & 14.16 & $5,296.5$ & 14.54 & $5,782.9$ & 13.94 & 7.64 \\
\hline 64-67_Footwear & $2,059.9$ & 5.84 & $2,407.7$ & 6.61 & $2,722.7$ & 6.56 & 14.97 \\
\hline 68-71_StoneGlas & 815.0 & 2.31 & 873.1 & 2.40 & 999.5 & 2.41 & 10.74 \\
\hline 72-83_Metals & $1,131.9$ & 3.21 & $1,350.8$ & 3.71 & $1,503.1$ & 3.62 & 15.23 \\
\hline 84-85_MachElec & $13,153.2$ & 37.31 & $14,826.5$ & 40.69 & $16,091.4$ & 38.78 & 10.61 \\
\hline 86-89_Transport & 780.4 & 2.21 & 809.5 & 2.22 & 819.1 & 1.97 & 2.45 \\
\hline 90-99_Miscellan & $2,562.7$ & 7.27 & $2,887.9$ & 7.93 & $4,028.1$ & 9.71 & 25.37 \\
\hline Total & $35,255.3$ & 100.00 & $36,434.7$ & 100.00 & $41,496.6$ & 100.00 & 8.49 \\
\hline
\end{tabular}

Source: Calculated from UN comtrade

In CPTPP, Japan is Vietnam's largest trading partner with about 33.6 billion USD in trade, accounting for nearly $41.6 \%$ of the country's total import and export turnover with its partners in CPTPP. Two other Asian members, Singapore and Malaysia, are the second and third largest trading partners, with import and export values accounting for 19.37\% and 14.39\% of Vietnam's total import and export value in CPTPP 2017, respectively. Australia is also a major trading partner of Vietnam in the volume of USD 7.4 billion in 2017, accounting for $9.22 \%$ of the total (Table 2).

Regarding import-export growth in the period 2015-2017, except Brunei and Singapore, all remaining CPTPP markets witnessed annual growth of import and export of over $10 \%$, of which non-continental markets like New Zealand, Peru, Chile, and Mexico all have higher growth rates than other markets.

Table 2. Vietnam's trade by market in CPTPP in the period of 2015-2017

\begin{tabular}{|c|c|c|c|c|c|c|c|}
\hline \multirow[b]{2}{*}{ Country } & \multicolumn{2}{|c|}{2015} & \multicolumn{2}{|c|}{2016} & \multicolumn{2}{|c|}{2017} & \multirow{2}{*}{$\begin{array}{c}\text { Growth } \\
(\%)\end{array}$} \\
\hline & $\begin{array}{c}\text { Value } \\
\text { (\$ million) }\end{array}$ & $\%$ & $\begin{array}{c}\text { Value } \\
\text { (\$ million) }\end{array}$ & $\%$ & $\begin{array}{c}\text { Value } \\
\text { (\$ million) }\end{array}$ & $\%$ & \\
\hline Australia & $5,856.2$ & 8.58 & $6,069.0$ & 8.50 & $7,446.3$ & 9.22 & 12.76 \\
\hline Brunei & 85.4 & 0.13 & 74.3 & 0.10 & 59.4 & 0.07 & -16.61 \\
\hline Canada & $3,689.0$ & 5.40 & $4,123.0$ & 5.78 & $4,701.9$ & 5.82 & 12.90 \\
\hline
\end{tabular}




\begin{tabular}{crrrrrrr}
\hline Chile & 894.2 & 1.31 & 937.9 & 1.31 & $1,167.8$ & 1.45 & 14.28 \\
\hline Japan & $27,672.6$ & 40.52 & $29,228.1$ & 40.94 & $33,585.4$ & 41.57 & 10.17 \\
\hline Mexico & $3,859.9$ & 5.65 & $5,054.1$ & 7.08 & $4,908.0$ & 6.07 & 12.76 \\
\hline Malaysia & $9,309.6$ & 13.63 & $10,266.2$ & 14.38 & $11,622.4$ & 14.39 & 11.73 \\
\hline New Zealand & 784.2 & 1.15 & 809.2 & 1.13 & $1,092.5$ & 1.35 & 18.03 \\
\hline Peru & 416.1 & 0.61 & 472.2 & 0.66 & 555.3 & 0.69 & 15.52 \\
\hline Singapore & $15,719.7$ & 23.02 & $14,355.9$ & 20.11 & $15,652.4$ & 19.37 & -0.21 \\
\hline Total & $68,286.8$ & 100.00 & $71,390.1$ & 100.00 & $80,791.4$ & 100.00 & 8.77 \\
\hline
\end{tabular}

Source: Calculated from UN comtrade

\section{Literature Review and Research Methodology}

Since its introduction by Tinbergen (Timbergen J. 1962), the gravity model has been extensively used in numerous studies of international trade (Kepaptsoglou, K., Karlaftis, M., Tsamboulas, D., 2010). Studies applying gravity model that focused on Vietnam include those by Do, T. T. (2006) explain bilateral trade between Vietnam and 23 European countries in the period of 1993-2004; Bac, N. X. (2010) examine the determinants of the Vietnamese export flows with her 15 key trading partners from 1991 to 2006; Dinh Thi Thanh Binh, Nguyen Viet Duong and Hoang Manh Cuong (2011) analyze bilateral trade activities between Vietnam and 60 countries from 2000 to 2010; $\mathrm{Su}$ Ha, Van \& Hoi, Le. (2019) uses gravity model to forecast the impact of Vietnam's CPTPP participation on the increase in exports for the 1995-2016 period; P.V. Nho, V.T. Huong (2014) analyzes the determinants of service trade flows between Vietnam and the European Union, etc. All of above studies use conventional variables in gravity model of trade such as GDP and distance. However, not all important factors affecting trade flows such as foreign direct investment, exchange rate, or income difference... are included in these studies. In addition, to our best knowledge, there is only one study in the context of Vietnam-CPTPP trade. Thus, this paper will contribute to fulfilling the gap in the literature on Vietnam and CPTPP trade.

The model applied in this study is an augmented version of the traditional gravity model. The model is modified by using export volume as dependent variable; tariff, GDP; difference in GDP per capita; foreign direct investment (FDI); exchange rate; distance as explanatory variables. The estimated model is as follow:

$$
\begin{aligned}
\log \left(\text { Export }_{i j t}\right) & \\
& =\beta_{0}+\beta_{1} \log \left(G D P_{j t}\right) \\
& +\beta_{2} \log \left(D G D P_{i j t}\right) \\
& +\beta_{3} \log \left(\text { Tarif }_{i j t}\right)+\beta_{4} \log \left(F D I_{i j t}\right)+\beta_{5} \log \left(E X R_{i j t}\right)+\beta_{6} \log \left(\text { DIST }_{i j t}\right)+\beta_{7} \mathrm{FTA}+\varepsilon_{i j t}
\end{aligned}
$$

This equation includes "standard" variables of the gravity model as follows:

- Average GDP $\left(G D P_{i j t}\right)$, which is an indicator of the average economic size of the two countries. GDP data is expressed in current million US dollars. These two variables are expected to have positive impact on the trade promotion. The average of GDP are used as measure of economic size, in terms of both production and market. Larger economies are more likely to increase their exports based on the advantage of economies of scale. These countries with large domestic markets are also to absorb more imports. Therefore, an increase in average GDP is expected to increase Vietnam's exports.

- Distance (DIST): is the distance between the capitals of Vietnam and CPTPP countries. The distance between countries as an alternative to the cost of transportation. This variable is expected to have negative impact on trade flows because of transportation cost.

- Bilateral tariffs $\left(\operatorname{tariff} f_{j j t}\right)$, which represents the barrier to trade. Bilateral tariffs are CPTPP's effectively applied rates on Vietnam's exports. Obviously, Vietnam's exports are expected to increase when CPTPP's tariff decrease.

Besides that, other variables such as Income dissimilarity, FDI, exchange rate, FTA...can be explained as follows: 
Income dissimilarity (DGDPP): it is the absolute difference in GDP per capita between Vietnam and CPTPP countries. Greater similarity with respect to GDP per capita implies increased similarity in size of the country-specific product diversity in the differentiated goods sector (Breuss and Egger, 1999). Due to variety in consumers' taste, increased similarity yields an increased trade volume. Therefore, a negative association between income dissimilarity and export would be expected.

Foreign Direct Investment $(F D I)$ : is the net inflow of Vietnam FDI in terms of percentage of GDP. When FDI is vertical (multinational firms geographically split stage of production) FDI stimulates trade. Vertical multinationals are firms, which geographically fragment the production process by stages (Markusen, 1998). The outsourcing of production to developing countries is related to the manufacture of goods intended for export (Blomström, 1990). Thus, FDI's coefficient is expected to be positive.

Exchange rate $(E X R)$ : is The Nominal Exchange Rate between respective countries. The exchange rate acts as a proxy for export and import price which either facilitating or restricting trade between countries. An increase in exchange rate means that Vietnam's currency devalued, as a result imports would be more expensive and exports would be cheaper. Therefore, exchange rate variable is expected to have a positive effect on trade between Vietnam and the partners.

FTA: the FTA dummy variable captures the effect of free trade agreements between the countries in CPTPP and Vietnam. The dummy for free trade agreements is also expected to be positive due to vanished trade barriers between Vietnam and CPTPP countries.

Trade potential is an important concept, which has been extensively used by researchers in international trade studies. Trade potential refers to the case when trade between the two countries is supposed to have reached its potential. This can be estimated on the basis of the gravity model of trade, by which estimated coefficients from the model are used in simulations to predict the trade volume between the two countries, given that data on GDP, distance, and population, etc. The simulated or predicted trade value is then compared with the actual trade value is regarded as the potential space for Vietnam - CPTPP trade. This methodology can be applied either at the aggregate or industry level (Helmers et al., 2005)

Data set contains annual and bilateral flows. Description of explanatory variables and expected signs are summarized in the Table 3.

Table 3. Variables used, expected sign and data sources

\begin{tabular}{|c|c|c|c|}
\hline $\begin{array}{l}\text { Variable } \\
\text { name }\end{array}$ & Variable description & $\begin{array}{l}\text { Expected } \\
\text { sign }\end{array}$ & Data sources \\
\hline GDP & Average GDP (in current USD) of two countries & + & World bank data \\
\hline DGDP & Difference in GDP per capital of two countries & - & World bank data \\
\hline Tariff & Partner's effective tariff rate on Vietnam's export & - & TRAIN \\
\hline FDI & Vietnam's FDI net inflows (\% of GDP) & + & World bank data \\
\hline EXR & $\begin{array}{l}\text { The Nominal Exchange Rate between Vietnam and } \\
\text { CPTPP countries }\end{array}$ & + & World bank data \\
\hline DIST & Distance between Vietnam and CPTPP countries & - & CEPII \\
\hline FTA & $\begin{array}{l}\text { The dummy variable taking value of } 1 \text { if two } \\
\text { countries is in same FTA, otherwise, FTA equal to } 0\end{array}$ & + & WTO center \\
\hline
\end{tabular}

The influences of specific factors on Vietnam's export to CPTPP in the studied period are evaluated based on panel framework. In panel data, three main estimators are pooled ordinary least squares (OLS), fixed-effects (FE) and random-effects (RE) which alternatively used in this type of study. The problem of OLS estimator is that it neglects the heterogeneity across individuals and assumes the same coefficients for all individuals, the estimates from pooled OLS regression will be usually biased and inconsistent. A RE model can be more appropriate when estimating the flows of trade between a randomly sample drawn of trading partners from a large population. A FE model would be a better model when estimating the flows of trade between ex ante predetermined selection of countries (Egger, P., 2000). In order to decide to choose appropriate model, we consider the properties of the data as well as apply the Hausman test to check the efficiency of FE and RE model. Since this study empirically test whether the bilateral 
trade between Vietnam and CPTPP would follow the traditional gravity theory, the results of all three models are reported for comparison purpose.

\section{Estimation Results}

The results of panel pooled OLS, REM, and FEM regression for the proposed model are presented in Table 5. In general, The estimated models are significant in terms of explanatory power with R-squared values of all models are above 0.74 . Most of explanatory variables used in the models are statistically significant at the 10 percent level or better, indicating that Vietnam-CPTPP's bilateral trade flows is effectively explained by gravity model. The result from Hausman test (Table 4) implies that the null hypothesis (RE) has been rejected. Thus, we focus the interpretation on results of FE model.

Table 4. Hausman test for random effects model

\begin{tabular}{lrrr}
\hline $\begin{array}{l}\text { Correlated Random Effects - Hausman Test } \\
\text { Equation: Untitled } \\
\text { Test cross-section random effects }\end{array}$ & & & \\
\hline Test Summary & Chi-Sq. Statistic & Chi-Sq. d.f. & Prob. \\
\hline Cross-section random & 151.127743 & 6 & 0.0000 \\
\hline
\end{tabular}

As can be seen from Table 5, both CPTPP's GDP and Vietnam-CPTPP income dissimilarity have the expected signs and reasonable magnitude. These results mean that Vietnam's exports to CPTPP will increase by 5.597 percent and decrease by 4.22 percent as average Vietnam-CPTPP GDP and income dissimilarity increases by 1 percent, respectively. Likewise, the coefficient of the tariff variable implies that, when the CPTPP's tariff rates increase by 1 percent on average, Vietnam's exports will decrease by 0.333 percent.

The effect of exchange rate on bilateral trade is consistent with theory background and the largest magnitude among variables, which suggests that exchange rate has significant effect on trade between Vietnam and CPTPP countries. Similarly, net inflow of FDI in Vietnam will stimulates exports from Vietnam to CPTPP due to vertical investment and the outsourcing of production from multinational firms.

In terms of geographical distance, this is a traditional variable of the gravity model, although not estimated in the FE model but in the Pooled OLS and RE models, the coefficient has the sign as expected and shows a great impact on Vietnam's exports to CPTPP. For FTA dummy variables, although only statistically significant in the RE model, it is also pointed out that the FTA between Vietnam and CPTPP members also has a certain impact on bilateral trade between the two parties.

Table 5. Regression results

\begin{tabular}{|c|c|c|c|}
\hline Explanatory Variable & Pooled OLS & $\mathbf{F E}$ & $\mathbf{R E}$ \\
\hline GDP & $1.153 * * *$ & $5.597 * * *$ & $1.498 * * *$ \\
\hline GDPP & $-0.729 * * *$ & $-4.220 * * *$ & $-0.443 * * *$ \\
\hline TARIFF & $-0.082 * * *$ & $-0.333 * * *$ & $-0.092 * * *$ \\
\hline FDI & $0.455^{\text {ns }}$ & $0.236^{*}$ & $0.710^{* * *}$ \\
\hline EXCHANGE RATE & $-0.003^{\text {ns }}$ & $0.662 * *$ & $0.151 * * *$ \\
\hline DISTANCE & $-1.263 * * *$ & - & $-0.402 * * *$ \\
\hline FTA & $-0.186^{\mathrm{ns}}$ & $0.117^{\text {ns }}$ & $0.849 * * *$ \\
\hline Adjusted R-squared & 0.745 & 0.955 & 0.776 \\
\hline Observations & 139 & 139 & 139 \\
\hline
\end{tabular}

Notes: ns-not significant; ${ }^{* *}, * *$ and $*$ mean significant at $1 \%, 5 \%$ and $10 \%$ level, respectively. 


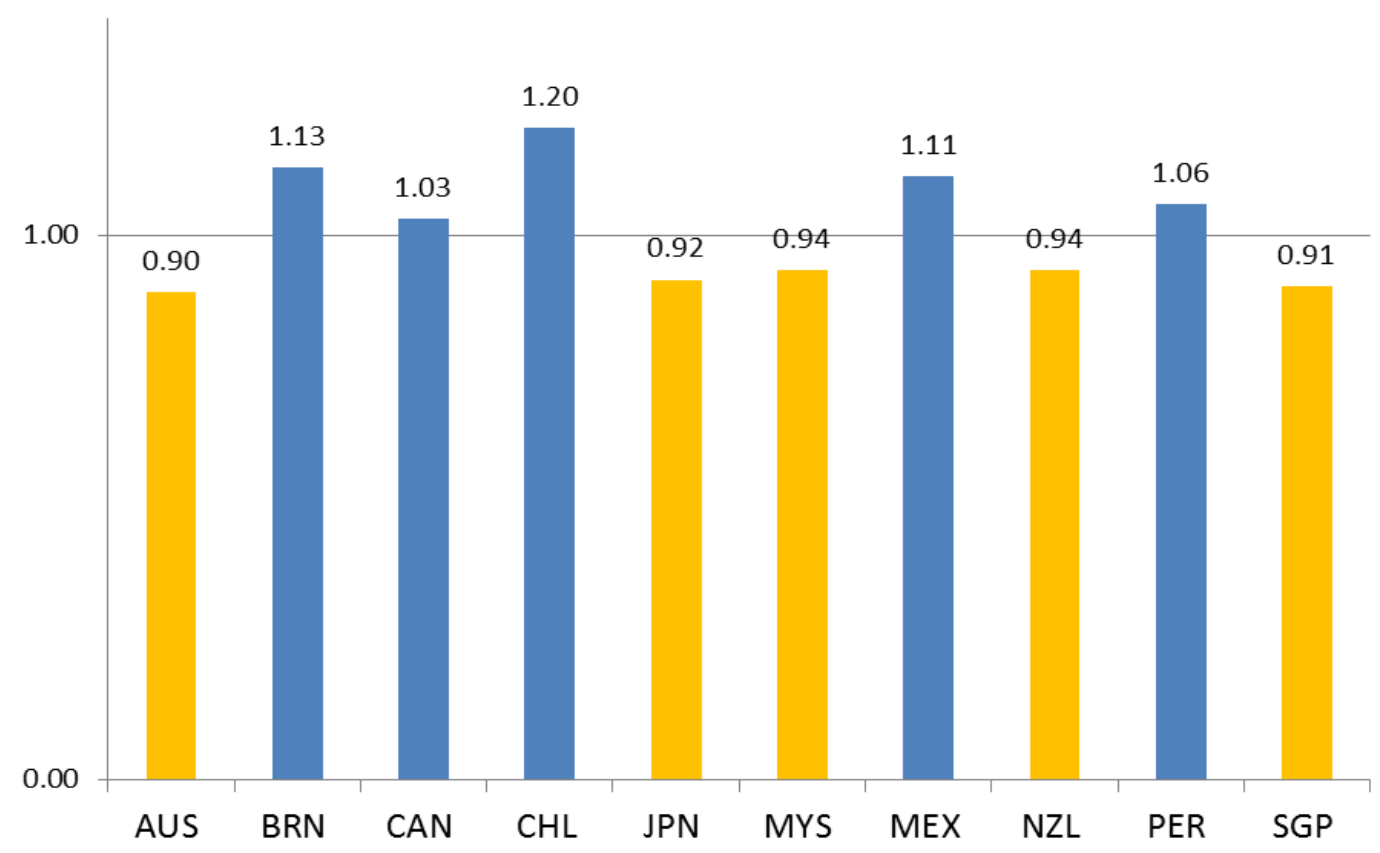

Figure 1. Actual vs. predicted trade ratio

The estimation of gravity model is considered as a long-run equilibrium of trade flows. Thus, the gap between this long-run equilibrium value and the actual trade value is interpreted as the "trade potential". The basic gravity model was estimated for Vietnam-CPTPP export flow for a long period (2003-2016). Then, the trade potential is calculated by using the ratio of actual trade - AT, to predicted trade - PT, which is the trade value estimated from the dependent variable. If the value of AT/PT ratio is less than 1, this implies that Vietnam's export to CPTPP will be potentially expanded. For each market, the AT/PT ratio is computed as an average of annual growth rates of AT/PT. As shown in figure 1, half of markets have AT/PT ratio less than 1; for instance, Australia, Japan, Malaysia... have AT/PT values less than 1, which indicates that Vietnam's exports to CPTPP will be potentially expanded in these countries.

\section{Conclusion}

This paper aims to evaluate the factors affecting Vietnam-CPTPP export performance and to predict the trade potential between Vietnam and CPTPP using gravity model estimates. The results show that Vietnam's exports to CPTPP are influenced by economic size (GDP), income gap, bilateral tariffs, FDI, and exchange rate. Although Vietnam-CPTPP trade has grown faster for many years, trade relation, in general, is still under potential levels. Among the impact factors, economic size, exchange rate, and FDI have a significant positive impact, while the income gap has a strong negative impact on Vietnam's exports to CPTPP. This implies that macroeconomic management should be focused on economic growth, attraction of foreign direct investment, and adjustment of exchange rates to optimize the export potential of Vietnam in CPTPP. This finding would be useful for policy-maker in terms of proposing solutions to exploit these trade potentials for Vietnam in the future.

The limitations of this research can be: (i) the paper does not include all possible factors affecting trade flows between Vietnam and CPTPP such as: language, regional trade agreements, etc; (ii) although this study has estimated the potential trade of Vietnam-CPTPP, the results are limited mainly because of applied technique; and (iii) there are many techniques for estimating the gravity model that cannot be considered all in this study. Therefore, it is worth considering all of above in any future study.

\section{References}

Bac, N. X. (2010). The Determinants of Vietnamese Export Flow: Static and Dynamic Panel Gravity Approaches. International Journal of Economics and Finance, 2(4). 
Blomström, M. (1990). Transnational Corporations and Manufacturing Exports from Developing Countries. Ed. United Nations Centre on Transnational Corporations, New York.

Breuss, F., \& Egger, P. (1999). How Reliable Are Estimations of East-West Trade Potentials Based on Cross-Section Gravity Analyses?. Empirica, 26(2), 81-94.

Dinh Thi Thanh Binh, Nguyen Viet Duong, \& Hoang Manh Cuong. (2011). Applying Gravity Model to Analyze Trade Activities of Vietnam. FREIT Working Paper 639.

Do, T. T. (2006). A gravity model for trade between Vietnam and twenty-three European countries. Department of Economics and Society, Dalarna University, Sweden.

Egger, P. (2000). A Note on the Proper Econometric Specification of the Gravity Equation. Economics Letters, 66, 25-31. https://doi.org/10.1016/S0165-1765(99)00183-4

Helmers, C., \& Pasteels, J. M. (2005). TradeSim (Third Version): A Gravity Model for the Calculation of Trade Potentials for Developing Countries and Economies in Transition. Geneva: International Trade Centre.

Kepaptsoglou, K., Karlaftis, M., \& Tsamboulas, D. (2010). The gravity model specification for modeling international trade flows and free trade agreement effects: a 10-year review of empirical studies. Journal of Open Economics, (3), 1-13.

Markusen, J. R. (1998). Multinational Firms, Location and Trade. The World Economy, 21(6), 733-756.

Nho, P. V., \& Huong, V. T. (2014). Analyzing the Determinants of Service Trade Flows Between Vietnam and the European Union: A Gravity Model Approach. VNU Journal of Science: Economics and Business, 30(5E), 51-64.

Su Ha, V., \& Hoi, L. (2019). The impact of participation in the comprehensive and progressive trans-pacific partnership agreement on exports: The case of Vietnam. Management Science Letters, 1269-1280. https://doi.org/10.5267/j.msl.2019.4.015

Timbergen, J. (1962). Shaping the world economy. New York, NY: Twentieth Century Fund.

United Nations Statistics Division (UNSD). (2018). United Nations Commodity Trade Statistics Database. Retrieved from http://comtrade.un.org/db/default.aspx

\section{Copyrights}

Copyright for this article is retained by the author(s), with first publication rights granted to the journal.

This is an open-access article distributed under the terms and conditions of the Creative Commons Attribution license (http://creativecommons.org/licenses/by/4.0/). 